\title{
Editorial
}

\section{Assessment and Governance of Sustainable Soil Management}

\author{
Katharina Helming ${ }^{1,2, *}$, Katrin Daedlow ${ }^{3}$, Bernd Hansjürgens ${ }^{4}$ and Thomas Koellner ${ }^{5}$ (D) \\ 1 Leibniz Centre for Agricultural Landscape Research (ZALF) e.V., 15374 Müncheberg, Germany \\ 2 Eberswalde University for Sustainable Development, 16225 Eberswalde, Germany \\ 3 Division Agriculture and Food Policy, Humboldt-Universität zu Berlin, 10099 Berlin, Germany; \\ daedlowk@agrar.hu-berlin.de \\ 4 Helmholtz Centre for Environmental Research-UFZ, Permoserstraße 15, 04315 Leipzig, Germany; \\ bernd.hansjuergens@ufz.de \\ 5 Professorship of Ecological Services, Faculty of Biology, Chemistry and Earth Sciences, BayCEER, \\ University of Bayreuth, Universitaetsstr. 30, 95440 Bayreuth, Germany; thomas.koellner@uni-bayreuth.de \\ * Correspondence: helming@zalf.de; Tel.: +49-(0)33432-82155
}

Received: 5 November 2018; Accepted: 7 November 2018; Published: 27 November 2018

\begin{abstract}
The globally increasing demand for food, fiber, and bio-based products interferes with the ability of arable soils to perform their multiple functions and support sustainable development. Sustainable soil management under high production conditions means that soil functions contribute to ecosystem services and biodiversity, natural and economic resources are utilized efficiently, farming remains profitable, and production conditions adhere to ethical and health standards. Research in support of sustainable soil management requires an interdisciplinary approach to three interconnected challenges: (i) understanding the impacts of soil management on soil processes and soil functions; (ii) assessing the sustainability impacts of soil management, taking into account the heterogeneity of geophysical and socioeconomic conditions; and (iii) having a systemic understanding of the driving forces and constraints of farmers' decision-making on soil management and how governance instruments may, interacting with other driving forces, steer sustainable soil management. The intention of this special issue is to take stock of an emerging interdisciplinary research field addressing the three challenges of sustainable soil management in various geographic settings. In this editorial, we summarize the contributions to the special issue and place them in the context of the state of the art. We conclude with an outline of future research needs.
\end{abstract}

Keywords: soil functions; agricultural practices; sustainability assessment; ecosystem services; resource use efficiency; soil policy; soil governance

\section{Introduction}

Soils are at the nexus of multiple United Nations Sustainable Development Goals (SDGs) [1]. While Keesstra et al. [2] identified direct or indirect contributions of soils to as many as 13 of the 17 SDGs, a fundamental role of soils exists for at least four of them: arable soils account for the largest part of global food provision (SDG 2); soils are the basis for bio-based renewable energy production to ensure energy security (SDG 7); the storage capacity of soils for organic carbon is paramount for climate change mitigation (SDG 13); and the capacity for water purification and retention, nutrient and matter cycling, and the habitat function of soils are essential for maintaining the terrestrial environment and biodiversity (SDG 15). The link between soil processes and SDGs is usually conceptualized via soil functions [2]. Arable soils provide five key functions: biomass production, water purification, carbon sequestration, habitat for biodiversity, and recycling of nutrients and (agro)chemicals [3]. 
While agricultural soil management does, by definition, favor the production function over other functions, it is the challenge for sustainable soil management to maintain multifunctionality [4].

From a natural science perspective, it is important to understand how soil functions emerge from interacting soil processes. While soil sciences have impressively advanced knowledge about chemical, physical, and biological processes in soils, their interrelations and links to soil functions are not yet well understood. Such an understanding requires a systems approach to the development of indicators of soil functions [5]. Ludwig et al. [6] conceptualize the analysis of soil functions from the perspective of the social-ecological-systems framework [7] and propose the resilience of the soil system as an integrated sustainability indicator. This approach may allow for the identification of tipping points toward an irreversible or permanent loss of soil functions. However, the authors admit that the quantification of such an indicator remains out of sight. Bünemann et al. [8] provide a critical review of the assessment and indication of soil quality and function. They argue that the process of developing an indicator for soil quality and function assessments requires the involvement of actors, stakeholders, and end users in order to be useful for supporting management and policy decisions in practice.

While it is the task of natural science disciplines to jointly develop a systemic understanding of interactions of soil process with soil functions, it requires socioeconomic and agronomic expertise to address sustainable soil management. We see three challenges in developing socioeconomic and agronomic research in this context (Figure 1): (i) to establish analytical linkages between soil management and soil functions; (ii) to assess the relevance of soil functions to fulfilling societal targets, including ecosystem services, resource use efficiency, and sustainable development; and (iii) to understand how governance instruments affect farmers' decision-making regarding sustainable soil management. The three challenges establish linkages between the five elements of the DriversPressure-State-Impact-Response (DPSIR) framework [9], which is a well-established framework for the analysis of human/nature relationships (Figure 1).

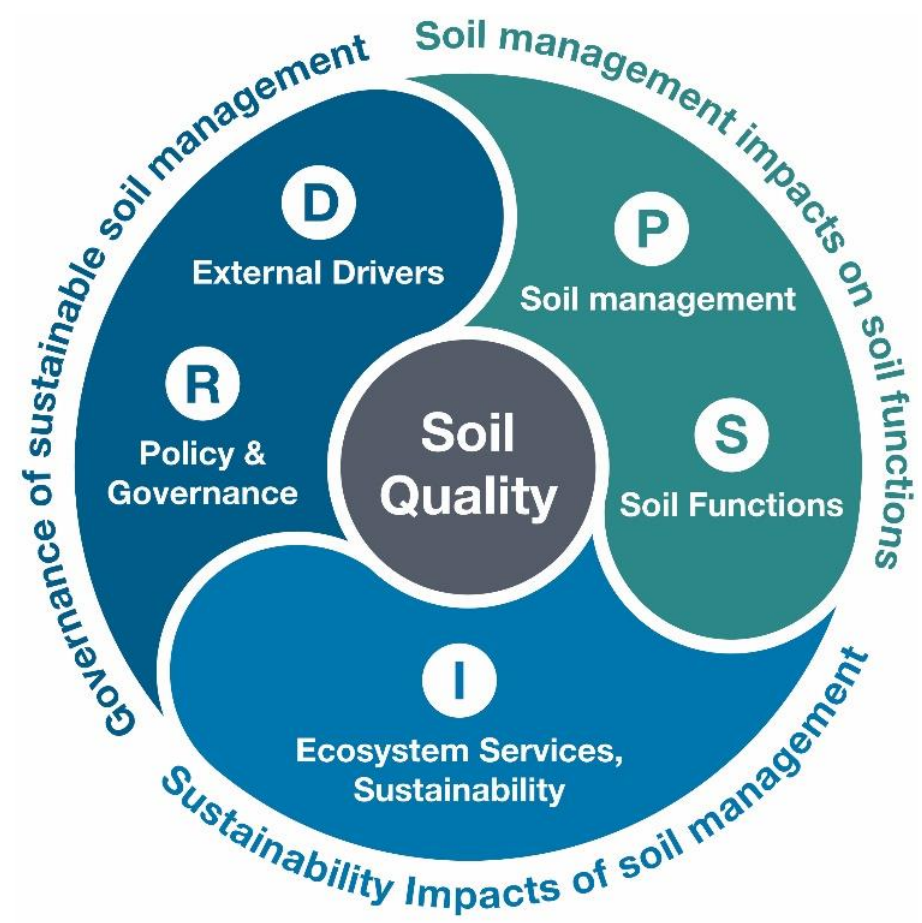

Figure 1. Three main analytical challenges for sustainable soil management. Letters indicate the relationship to the Drivers-Pressure-State-Impact-Response (DPSIR) framework for analyzing human/nature interrelations [9]. 
The first challenge is to understand soil management practices and how they impact soil processes and functions. Agricultural crop management includes tillage, crop choice and rotation, fertilization, weed management, pest management, irrigation and drainage, harvesting, and residue management. Each of these activities interferes with soil processes. Soil conservation practices such as conservation tillage aim at avoiding soil threats and maintaining soil multifunctionality, which often is at the cost of yield performance [10]. Policy instruments such as the agri-environmental payment schemes of the European Common Agricultural Policy (CAP) aim at compensating farmers for income loss associated with soil conservation management practices [11]. However, with the globally increasing demand for biomass-based food, feed, energy, and fiber, not least reinforced through renewable energy policies or bioeconomy strategies, the quest for sustainable intensification practices is expressed, which aims at integrating the highest productivity with the maintenance of a broad range of soil functions $[12,13]$. This integration requires the stimulation of ecological interactions at the soil-plant interface, thereby improving the efficiency of natural resource use [14]. Emerging management technologies associated with, for example, smart farming technologies [15] or improved use of biological pest antagonists [16] are expected to offer potential for the implementation of sustainable intensification [17]. However, institutional factors (e.g., regulations, prices, norms, habits) and policy conditions for their implementation (e.g., market factors, enforcement), along with possible interference with farm management constraints and their impacts on a wider set of sustainability goals, have yet to be assessed.

Sustainability assessment of soil management is the second challenge of providing an evidence base for sustainable soil management. This process involves assessing intended and unintended, direct and indirect impacts of human activities on societal targets such as the UN sustainable development goals [18]. Assessments are applied at the level of EU and national policy, regional landscape planning, and farmers' practices [19]. Helming et al. [4] developed a conceptual framework for the sustainability assessment of soil management that links the concepts of resource use efficiency and ecosystem services to account for the most prominent perspectives. This framework involves a dynamic ex ante approach that builds upon the DPSIR framework [9] and links external driving forces to soil management, soil process changes, and their implications for sustainability targets. While the concept is comprehensive, its implementation is challenged by the multitude of indicators that must be estimated, valued, and prioritized for specific geophysical and socioeconomic contexts. Targeted data collection, research synthesis methods, and user-oriented approaches are key to successfully conducting such dynamic assessments [20]. For example, a stakeholder-inclusive process of indicator selection for the assessment of soil management may improve its relevancy for sustainable development targets [21].

The outcomes of sustainability assessments can be seen as a prerequisite for the third challenge of providing an evidence base for sustainable soil management, which is related to governance mechanisms and policy-making. Although a number of publications have emerged in recent years about policy analysis regarding soil management, particularly in Europe [11,22,23], soil-related governance is far less well understood than the governance of other natural resources such as water, air, or biodiversity [24]. Research must reveal how governance mechanisms at multiple administrative levels interact, which instruments are most relevant for farmers' decision-making, what role property rights and tenure systems may play in the efficiency of governance instruments, and how governance interacts with other drivers of soil management, such as climate change, technological advances, consumer preferences, and education and advisory systems.

The objective of this special issue is to compile the latest interdisciplinary research on the three challenges outlined above. The idea is to shed light on the emergence of an interdisciplinary research community dealing with the sustainable management of soils. The motivation for this project stems from the German interdisciplinary research program "Soil as a Sustainable Resource for the Bioeconomy-BonaRes" (www.bonares.de), which was established to develop a scientific evidence base for agricultural soil management that maintains soil functions while increasing agricultural production in support of the implementation of the German bioeconomy strategy. The BonaRes program 
consists of 10 collaborative research projects on various aspects of sustainable soil management. It is complemented by the BonaRes Centre to develop a coherent approach to data management, soil modeling, sustainability assessment, and governance [25]. While the core of research in BonaRes focuses on the natural science aspects of soil management, processes, and functions, there is increasing awareness about the role of socioeconomic research to better understand the full complexity of, the opportunities for, and the obstacles to sustainable soil management. Taking the interdisciplinary setting of BonaRes as a stepping-stone, this special issue invited interdisciplinary and transdisciplinary research on the assessment and governance of sustainable soil management from various contexts across the globe. The outcome is 15 papers dealing with the management, assessment, and governance of agricultural soils and their relationship to soil functions, ecosystem services, and sustainable development. The papers address a wide range of agronomic practices and include reviews, conceptual papers, meta-analyses, and empirical studies of cases in Europe, Central America, the Middle East, and Asia. The papers are outlined and placed in the context of the three research challenges described in the following sections.

\section{Soil Management Impacts on Soil and Soil Functions}

Soil management of arable fields is performed to improve the growth conditions for agricultural crops. Soil management thereby favors the production function of soils over other functions, with the target of producing food, feed, and fiber. However, soil degradation processes are negative side effects that seem to be exacerbated by increasing agricultural intensity [26]. Agricultural production is therefore considered a major cause of soil degradation processes. These processes include erosion by wind and water, loss of biodiversity, compaction, salinization, loss of organic carbon, and diffuse water and soil pollution [22]. The cause-effect chains between agricultural management practices, on the one hand, and soil degradation processes, on the other, are not straightforward. These chains are subject to spatially varying geophysical and climatic site conditions as well as the temporal dynamics of weather and vegetation processes. For example, water erosion occurs on sloped land when precipitation exceeds the infiltration capacity of the soil, but that is highly dependent on the vegetation status and the coverage of the soil surface with plant material [27]. The same holds true for wind erosion, which soils are particularly susceptible to when the surface is bare and dry [28]. The design of crop rotations and tillage practices determines the length of time during which the soil is bare during the vegetation year. Conservation agriculture is defined as an approach to optimizing coverage of the soil surface with organic material and improving the soil's infiltration and water-retention capacity [29]. It combines no-till practices with residue management and differentiated crop rotations.

In this special issue, several papers analyze the impacts of conservation agriculture and other innovative soil management practices on soil functions (Table 1). Ghaley et al. [30] provide a meta-analysis of the effects of conservation agriculture on soil multifunctionality for the main environmental zones of Europe. Building upon a literature synthesis and employing an expert-based scoring system, the authors identify overall positive effects of conservation agriculture, while in the case of conventional agriculture, negative effects dominate across the five soil functions mentioned above (production, water purification, carbon sequestration, habitat for biodiversity, and recycling of nutrients and (agro)chemicals). Ghaley et al. [30], however, point to the need for field investigations to better understand systemic factors of soil management, climate, soil process interactions that lead to changes in soil functions, and associated ecosystem services.

Lalani et al. [31] employ a farm research approach to study the impacts of conservation agriculture on dryland farming systems in central Syria. Although the research was restricted by the outbreak of armed conflict in Syria, preliminary results indicate that conservation agriculture is of particular benefit for soil moisture and for grain and straw productivity. The authors conclude that in a semi-arid marginal area such as central Syria, conservation agriculture may be the only option with progressing climate change because of its moisture-saving characteristics [31]. 
Nuppenau [32] takes the complex system relationships between crops and soils as a starting point from which to design a dynamic optimization modeling approach for crop rotations that better considers ecological information and feedback loops. Such an approach is also meant to account for the long-term positive effects of deep-rooting and/or N-fixating crops such as alfalfa on soil structure, organic turnover, organic carbon sequestration, soil rootability, and water capacity. Such positive effects may, in the long run, outweigh the short-term negative effects on economic return compared to other crop rotations. Addressing long-term effects in complex modeling approaches is indeed important to reveal and assess possible benefits of conservation agriculture practices that, from the short-term view, still suffer from lower yields and economic returns compared to conventional practices [10].

Table 1. Overview of contributed papers addressing the impacts of soil management on soil functions.

\begin{tabular}{|c|c|c|c|c|c|}
\hline Authors & $\begin{array}{c}\text { Soil Management } \\
\text { Type }\end{array}$ & $\begin{array}{c}\text { Soil Management } \\
\text { Topic }\end{array}$ & Region & Spatial Scale & $\begin{array}{c}\text { Paper Type; } \\
\text { Knowledge Base }\end{array}$ \\
\hline Ghaley et al. [30] & $\begin{array}{l}\text { Tillage, crop rotation, } \\
\text { residue management }\end{array}$ & $\begin{array}{l}\text { Effects on soil } \\
\text { functions }\end{array}$ & Europe & Field & Meta-analysis \\
\hline Lalani et al. [31] & $\begin{array}{l}\text { Tillage and soil } \\
\text { moisture retention }\end{array}$ & $\begin{array}{c}\text { Yield, } \\
\text { cost-effectiveness, } \\
\text { trade-offs }\end{array}$ & Syria & Farm & $\begin{array}{l}\text { Empirical } \\
\text { analysis }\end{array}$ \\
\hline Nuppenau [32] & Crop rotations & $\begin{array}{l}\text { Economic optimization } \\
\text { and ecosystem services }\end{array}$ & Germany & Farm & $\begin{array}{l}\text { Modelling } \\
\text { framework }\end{array}$ \\
\hline $\begin{array}{l}\text { Frelih-Larsen et al. } \\
\text { [33] }\end{array}$ & Subsoil management & Farmers' acceptance & Germany & Farm & $\begin{array}{l}\text { Empirical } \\
\text { analysis }\end{array}$ \\
\hline $\begin{array}{c}\text { Seydehmett et al. } \\
\text { [34] }\end{array}$ & $\begin{array}{l}\text { Water utilization and } \\
\text { management }\end{array}$ & $\begin{array}{l}\text { Future trends and soil } \\
\text { salinization }\end{array}$ & $\begin{array}{l}\text { China/northwest } \\
\text { region }\end{array}$ & Landscape/region & $\begin{array}{l}\text { Modelling } \\
\text { analysis }\end{array}$ \\
\hline $\begin{array}{c}\text { Ledermüller et al. } \\
{[35]}\end{array}$ & Tillage, field traffic & $\begin{array}{l}\text { Risk assessment of soil } \\
\text { compaction }\end{array}$ & $\begin{array}{c}\text { Germany/Lower } \\
\text { Saxony }\end{array}$ & Field & $\begin{array}{l}\text { Spatial analysis } \\
\text { and modelling }\end{array}$ \\
\hline
\end{tabular}

The utilization of subsoil for root growth and water and nutrient utilization is another key factor of soil-improving agricultural practices [36]. Frelih-Larsen et al. [33] analyze determining factors for farmers' decision-making on the implementation of subsoil-improving management practices. These include biological measures such as integrating deep-rooting crops and mechanical practices. General acceptance of biological measures of subsoil utilization was found to be far higher than that of mechanical practices. However, economic barriers also hinder the integration of such crops into rotation [33].

In semi-arid and dryland regions, irrigation of crops is one major cause of soil degradation risk because of secondary salinization. Irrigated agriculture accounts for more than $40 \%$ of global food production, and it covers nearly one-fifth of the world's cropland [37]. The degree of soil salinization is a factor of natural soil properties, climate, water quality, and farmers' decisions regarding the technology and amount of irrigation, as well as desalinization measures such as leaching. In their contribution to this special issue, Seydehmet et al. [34] apply a Bayesian networks approach to integrate assumptions on farmers' decision-making into model simulations of future salinization for a Chinese watershed. Particularly because of the integration of stakeholder perceptions, the modeling approach proved to be a useful tool to support future decision-making on land reclamation and irrigation with regard to avoiding salinization.

The contribution by Ledermüller et al. [35] also reports on the development of a decision support tool for farmers to help avoid soil degradation. This tool addresses the problem of soil compaction caused by heavy machinery. Soil moisture determines the susceptibility of soils to compaction under mechanical pressure and is highly dynamic depending on temporal patterns of precipitation. Ledermüller et al. [35] integrated spatiotemporal factors into a risk map for soil compaction, which farmers can use to optimize the timing of traffic and tillage operations. Such decision-support systems are particularly important to assist farmers in better aligning soil management with soil function maintenance. 
Despite the variety of topics covered by the papers in this special issue, two items for future research stand out. The first is the need to acknowledge the systemic interrelations between agricultural soil management practices and soil process reactions leading to responses in soil functions [5]. Linear processes and one cause-one effect relationships rarely exist in soils, which makes the identification of best management practices complex. In particular, long-term effects and feedback loops must be accounted for to best capture the impact of alternative soil management practices on soil functions. The second future research item is the need to develop methods of synthesizing scientific evidence into support for farmers and other decision-makers regarding soil management.

\section{Sustainability Assessment of Soil Management, Analysis of Trade-Offs and Synergies}

Sustainable soil management implies not only the proper maintenance of soil quality, but also the need to comply with farm management constraints and a wider set of environmental and socioeconomic targets, as set out in the SDGs [2]. The assessment of soil management impacts on multiple targets, as well as trade-offs and synergies between them, provides an important evidence base for decision-making at the farming system and policy-making levels. Such an assessment must be forward-looking (ex ante) so that it can anticipate possible impacts of alternative management options before decisions are made [38]. Scenario techniques are often used to capture technological, economic, and climatic driving forces and future frame conditions in which the soil management options are embedded [39]. The assessment also needs to capture a wide range of environmental and socioeconomic impact categories to allow for an analysis of intended and unintended, short-term and long-term impacts. Impact categories cover relevant societal aspects to which soils contribute. These emerge from soil functions and include, for example, food production, biodiversity conservation, climate action through carbon sequestration and mitigation of greenhouse gas emissions, flood control, disease control, and human health [2]. This list is not conclusive and depends on the specific conditions in which an assessment is placed, its geographic setting and purpose. Stakeholders involved in the assessment process may have their say in selecting and weighing impact categories, such as what is recommended in the Sustainability Assessment of Food and Agriculture (SAFA) guidelines [40]. The key point of the assessment is to identify synergies and trade-offs between the different impact categories as they are affected by soil management options.

Regarding the conceptualization of impact categories, the concept of ecosystem services (ES) is a prominent and well-elaborated approach to assess the services provided by ecosystems in support of human well-being [41]. The ES concept captures a wide range of regulating, cultural, and supporting services and builds on established scientific ground. Although the linkage between soil functions and ES is still subject to scientific debate [4], the potential for linking natural processes in the soil to societal aspects of human well-being is not contested [42].

In this special issue, four papers assess the impacts of soil management practices on economic aspects, ecosystem services, and sustainable development (Table 2). Schwilch et al. [43] provide an important step toward implementation of the ES concept related to soil management. They developed a factsheet-based scoring procedure for soil-related ES and applied it to 26 soil management measures on field trials across Europe. While direct measurements could be utilized to determine short-term impacts, expert-based estimations were used for long-term assessments. The results of both long-term and short-term assessments were meant to be a basis for stakeholder-based valuation of soil management practices. With this tested procedure, the authors close an important knowledge gap associated with the practical implementation of ecosystem service assessment. Nuppenau [32] uses the ES approach to conceptualize the assessment of crop rotation impacts with a dynamic optimization model. Similar to Schwilch et al. [43], he emphasizes the long-term effects of soil conservation management practices, which are not captured by many state-of-the-art assessments and modeling approaches. 
Table 2. Overview of contributed papers on sustainability assessment of soil management practices.

\begin{tabular}{cccccc}
\hline Authors & $\begin{array}{c}\text { Soil Management } \\
\text { Type }\end{array}$ & $\begin{array}{c}\text { Soil Management } \\
\text { Topic }\end{array}$ & Region & Spatial Scale & $\begin{array}{c}\text { Paper Type; } \\
\text { Knowledge Base }\end{array}$ \\
\hline $\begin{array}{c}\text { Schwilch et al. } \\
\text { [43] }\end{array}$ & $\begin{array}{c}\text { Specific management } \\
\text { practices }\end{array}$ & $\begin{array}{c}\text { Impact of } \\
\text { management on } \\
\text { ecosystem services }\end{array}$ & Europe & Plot/wider area & Meta-analysis \\
\hline Nuppenau [32] & Crop rotations & $\begin{array}{c}\text { Economic } \\
\text { optimization and } \\
\text { ecosystem services }\end{array}$ & Germany & Farm & $\begin{array}{c}\text { Modeling } \\
\text { framework }\end{array}$ \\
\hline $\begin{array}{c}\text { Correia and } \\
\text { Pestana [44] }\end{array}$ & $\begin{array}{c}\text { Carob tree } \\
\text { management }\end{array}$ & Cost-effectiveness & Portugal & Field/farm & Empirical \\
\hline $\begin{array}{l}\text { Quynh and } \\
\text { Kazuto [45] }\end{array}$ & Nitrate fertilizers & Nitrate use efficiency & Vietnam & Field & Empirical \\
\hline
\end{tabular}

While the ES concept is best placed for landscape-level assessments [46], farm-level assessments may bring into focus other impact categories, including economic measures such as cost-benefit ratios and risk attributes and measures of resource use efficiency. An example of farm-level assessment is provided by Correira and Pestana [44]. For a case study in Portugal, they assess the benefits and costs of planting carob trees as an alternative to high-intensity farming. In addition to exerting positive effects on ES through increased carbon sequestration in the soils, carob tree plantations can provide additional revenues for farmers and prove to be a measure of risk sharing under conditions of climate change. The latter two factors are particularly important for farm-level decision-making.

A third level of assessment is provided by Quynh and Kazuto [45]. The authors assess the impact of specific organic fertilizers on nutrient use efficiency and water quality. In this case, the production of organic fertilizers from the byproducts of coffee production is a good example of resource-efficient production, which is another paradigm of sustainable management [4]. Such a process proves, however, to have negative side effects on water quality because of the high leaching potential of the nitrogen compounds in the organic fertilizers. The conclusions are that such fertilizers from recycled materials need specific quality control mechanisms and cannot, per se, be said to be more sustainable compared to mineral fertilizers.

Sustainability assessment of soil management is a powerful tool to reveal linkages between soil functions and societal targets and values. At the same time, it provides a scientific evidence base for soil management at different levels of decision-making. In this regard, it serves as an important information base for the development of governance mechanisms that steer soil management in the direction of sustainable development. However, sustainability assessment of soil management is only an emerging scientific field. While promising methodological frameworks for its implementation exist [3,4,47], empirical implementation is still in its infancy. The papers of this special issue add to this emerging scientific field with important examples.

\section{Governance for Sustainable Soil Management}

Soil governance aims to regulate soil use and management in a way that meets societal targets and expectations. Soil governance structures include, for example, actors and decision-makers, property rights, formal and informal institutions, and regulations such as command-and-control or incentive-based policy instruments [24]. Although the sustainable use of soils, the prevention of soil degradation, and the maintenance of all soil functions are well-respected policy goals, their implementation remains flawed. Policy regulations are an outcome of comprehensive negotiation and deliberation in the policy formulation process, which ideally should imply impact assessments of policy options in order to deter unintended impacts. Sustainable soil governance requires a thorough understanding of the linkages between ecosystem services emerging from soil functions and impact assessments of soil management [4]. Furthermore, soil governance is affected by complex interrelations with other policy fields, such as the Common Agricultural Policy of the European Union (EU) or 
climate action and bioeconomy strategies. In addition, governance often takes place across several decision-making levels, from the farm level, over regional and national governance levels, to European and supranational scales, and incorporates manifold actors with different perceptions, values, and interests regarding soil management. These governance challenges are subject to comprehensive research, and the following contributions (Table 3) to this special issue help to close the knowledge gaps on sustainable soil governance.

Table 3. Overview of contributed papers on governance for sustainable soil management.

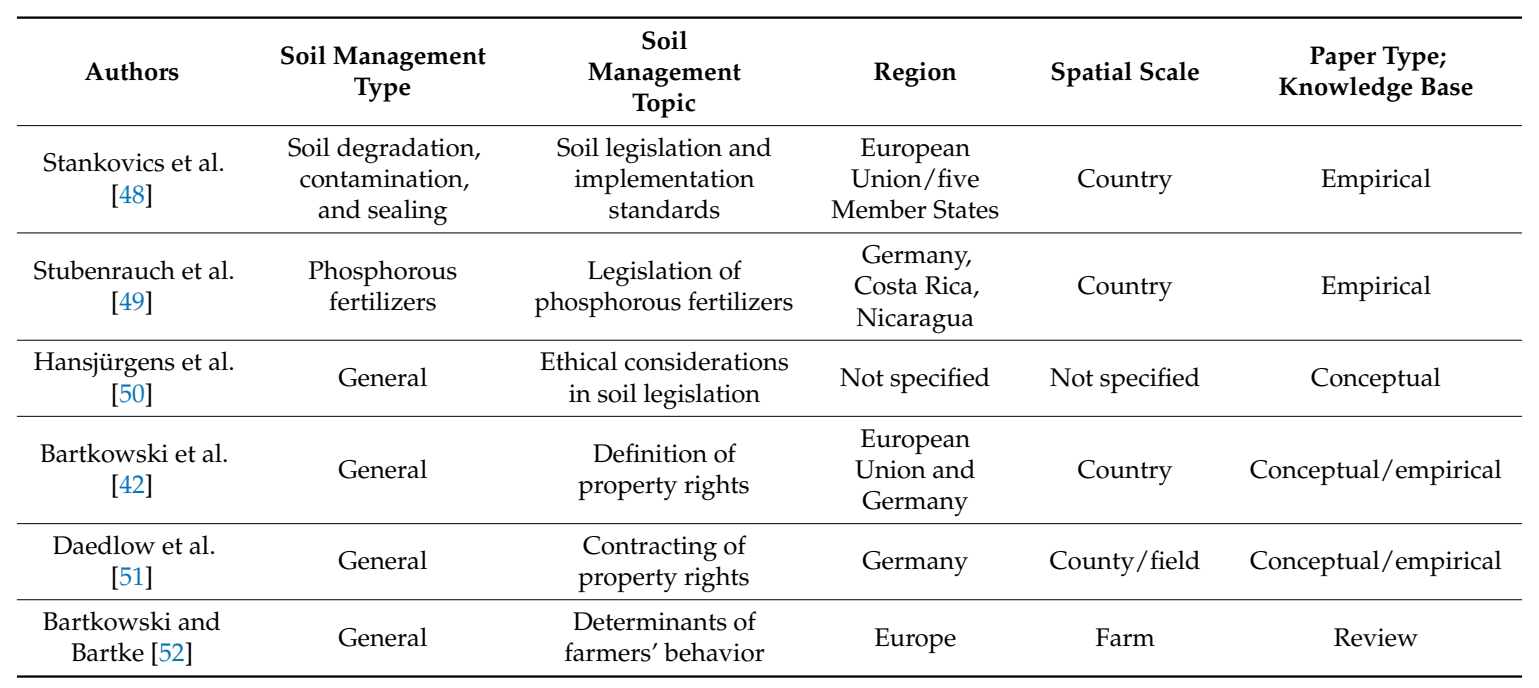

Two papers provide insights about emerging challenges in the formulation and implementation of soil regulations at the national and supranational levels that do not fully address the requirements of sustainable soil management. Stankovics et al. [48] investigate the obstacles, differences, and gaps in soil legislation and administration in five European countries (the United Kingdom, Germany, France, Austria, and The Netherlands) that could not agree on the proposal for a Soil Framework Directive in the EU in 2014. This lack of agreement ultimately resulted in the directive being refused. In these countries, issues of soil degradation and contaminated sites are generally well defined but are mostly embedded in environmental legislation, which makes soil issues a byproduct in environmental protection and results in a lack of reinforcement and liability. Due to divergent liability, levels of restriction, and some gaps in the content of soil protection, a harmonization of existing policies in EU member states toward a possible new Soil Framework Directive appears difficult.

Stubenrauch et al. [49] examine fertilizer legislation with regard to soil protection in Germany, Costa Rica, and Nicaragua and assess similarities and differences in the standardization and regulation of efficient fertilizer use in these countries. The authors found that in all three countries, the legislation does not comprehensively protect soils. In addition, control mechanisms of existing legislation are largely missing, and phenomena such as rebound and shifting effects of regulations and soil management are not addressed. Thus, from the authors' perspective, legislation in these countries does not fulfill its role as a driving force for sustainable soil management.

In their contribution on the ethical, legal, and economic considerations of soil protection, Hansjürgens et al. [50] focus on justifications for soil conservation legislation, with a particular emphasis on the creation-ethical arguments reinforced by Pope Francis in his encyclical Laudato $S i^{\prime}$ [53]. The authors show that the Pope's encyclical reveals a new relationship of the Catholic Church with nature (and soils). At the same time, such a relationship is reflected in legal prescriptions as provided by the German Constitutional Law and in economic arguments focusing on the definition of property rights regimes. These creation-ethical, legal, and economic considerations may serve as important reference points for soil conservation and sustainable soil management. They jointly 
emphasize that the long-term interests of the general public should be given priority over short-term private interests of farmers and landowners.

Two further papers address the issue of property rights and its linkage to soil characteristics and management. Bartkowski et al. [52] discuss how the concept of ecosystem services can be used to reassess the definition of current land property rights. The multifunctionality of soils implies that land property has special obligations regarding public welfare and suggests that current definitions of land property with a strong focus on private decision-making are imperfect from the perspective of the sustainable use of soils. The authors analyze two cases, the Common Agricultural Policy of the EU and German planning instruments, to demonstrate the inadequate consideration of soil multifunctionality in common private land property rights, which results in deficient internalization of externalities in agricultural markets. Policy instruments addressing such discrepancies could include, for example, taxation or incentives. The link between private property rights and soil quality is investigated by Daedlow et al. [51]. The authors contest theoretical assumptions about landowner and tenant relationships by studying empirical relations between soil quality, land rent prices, and land rent proportions at the county level in Germany. Given the manifold forms of ownership, the study challenges the general assumption that landowners take better care of their soils than tenants do. For example, it is shown that there is no direct correlation between rented arable land and low soil quality in Germany. The authors discuss the detected inconsistencies between theory and data that might emerge due to, for example, regulations of land markets, path dependencies in agricultural structures, and internalization of soil protection costs. The authors also stress the importance of examining the influence of the design of tenancy agreements with respect to soil conservation measures in future research.

Governance structures such as property rights are directly linked to farmers' decision-making about soil management. The importance of understanding this connection is shown by Bartkowski and Bartke [52], who review 78 European scientific studies about determinants of farmers' behavior and decision-making and link them to the assessment and development of soil governance instruments. Based on a conceptual framework, they investigate not only the social-institutional environment of farmers' decision-making, but also behavioral determinants, such as pro-environment attitudes, goodness of fit, and past experience. Research gaps in farmers' behavior include issues such as adoption of technologies, advisory services, bureaucratic load, risk aversion and social capital, social norms, and peer orientation. The authors stress the importance of a complex understanding of behavioral perspectives to improve the efficiency, effectiveness, and legitimacy of soil governance in general.

Despite an increasing number of studies published in recent years, soil governance research still needs to tackle many scientific gaps. For example, research about barriers and supporting factors that help to harmonize soil governance among the Member States of the EU and upscaling on the European level would help to establish efficient soil governance. Furthermore, the ecosystem services concept can be further applied to inform the design of soil management institutions, which would help to advance the understanding of the extent to which actual implementation of soil governance fails to address societal goals and cope with trade-offs. Likewise, living labs could be established where transdisciplinary research groups investigate to what extent impact assessments of soil management practices are considered in concrete policy formulation and implementation processes. Finally, studies identified the problem of unspecified soil policy instruments that often operate to a limited degree toward sustainability. Thus, soil governance research should address the development of tailor-made soil conservation instruments that specifically affect particular soil and land use types, as well as the design of corresponding soil property rights and land tenancy agreements.

\section{Conclusions and Recommendations}

Sustainable soil management of arable land means that biomass production for food, feed, and fiber can be integrated with soil functions to provide ecosystem services and contribute to sustainable development goals. Research can support sustainable soil management by providing an evidence 
base for the interrelationships between soil management practices and soil functions and between soil functions and sustainability targets. While there is agricultural management to produce biomass and maintain the economic basis of the farming enterprise, society and economy profit not only from agricultural goods, but also from other ecosystem services supported by soil functions. Nevertheless, trade-offs between provisioning services and habitat and between regulating and cultural services are evident. Such compromises stress the importance of developing new management approaches and assessing the impact of alternative management regimes on multiple outcomes in a comprehensive framework. To further this goal, close collaboration is needed between natural scientists trying to understand soil functions and social scientists and economists investigating how they can be transformed into services with social and economic value.

The contributions of this special issue provide examples of promising interdisciplinary research that places the use of soil within a wider societal context. These studies address challenges related to the management, assessment, and governance of soils. While each contribution emphasizes particular research questions, some common analytical challenges emerge. The first challenge is the understanding that one-size-fits-all management solutions do not exist. Rather, soil management must be adapted to site-specific geophysical and socioeconomic conditions. The second key challenge is the notion of time in the assessment and governance of soil management. Often, soil-improving management options turn out to be advantageous only after a long time period, while they are practically not suitable in the short term and without incorporating long-term effects. Efforts must be made to better understand such long-term management effects and to better address them in impact assessments. Furthermore, novel governance mechanisms are required that help farmers overcome short-term economic constraints and better gain the advantages derived from long-term soil quality. Such governance instruments can be justified, because sustainable soil management contributes to public goods in the long term, for which society should be ready to pay. This perspective leads to the third challenge, which is the interplay between private and public interests. While farmers have a private (business) interest to produce food, the other services provided by soil functions have the character of public goods. This private-public interrelationship is not yet well reflected in the property rights related to soils and must be better regulated by innovative governance mechanisms. With this special issue, an effort was made to shed light on the potential of an emerging interdisciplinary soil research community to advance the systemic understanding of sustainable soil management.

Author Contributions: All authors contributed substantially to the work reported. K.H. and K.D. designed the structure of the paper; K.H. wrote Sections 1-3, K.D. wrote Section 4, B.H. contributed to Section 4 and revised the manuscript, T.K. contributed to all chapters and revised the manuscript. All authors jointly developed the content of Section 5.

Acknowledgments: We are grateful to the authors of the various contributions to this special issue on Assessment and Governance of Sustainable Soil Management. We further thank all the reviewers for their time and suggestions for improving the manuscripts.

Conflicts of Interest: The authors declare no conflict of interest.

\section{References}

1. General Assembly. Transforming Our World: The 2030 Agenda for Sustainable Development, A/RES/70/1. Available online: http:/ /www.un.org/en/ga/search/view_doc.asp?symbol=A/RES/70/1 (accessed on 19 January 2016).

2. Keesstra, S.D.; Bouma, J.; Wallinga, J.; Tittonell, P.A.; Putten, W.H.; Mol, G.; Jansen, B.; Fresco, L.O. The significance of soils and soil science towards realization of the United Nations sustainable development goals. Soil 2016, 2, 111-128. [CrossRef]

3. Schulte, R.P.O.; Creamer, R.E.; Donnellan, T.; Farrelly, N.; Fealy, R.; O'Donoghue, C.; O'hUallachain, D. Functional land management: A framework for managing soil-based ecosystem services for the sustainable intensification of agriculture. Environ. Sci. Policy 2014, 38, 45-58. [CrossRef] 
4. Helming, K.; Daedlow, K.; Paul, C.; Techen, A.K.; Bartke, S.; Bartkowski, B.; Kaiser, D.; Wollschläger, U.; Vogel, H.J. Managing soil functions for a sustainable bioeconomy-Assessment framework and state of the art. Land Degrad. Dev. 2018, 29, 3112-3126. [CrossRef]

5. Vogel, H.J.; Bartke, S.; Daedlow, K.; Helming, K.; Kögel-Knabner, I.; Lang, B.; Rabot, E.; Russell, D.; Stößel, B.; Weller, U.; et al. A systemic approach for modeling soil functions. Soil 2018, 4, 83-92. [CrossRef]

6. Ludwig, M.; Wilmes, P.; Schrader, S. Measuring soil sustainability via soil resilience. Sci. Total Environ. 2018, 626, 1484-1493. [CrossRef] [PubMed]

7. Holling, C.S. Resilience and stability of ecological systems. Annu. Rev. Ecol. Syst. 1973, 4, 1-23. [CrossRef]

8. Bünemann, E.K.; Bongiorno, G.; Bai, Z.; Creamer, R.E.; de Deyn, G.; de Goede, R.; Fleskens, L.; Geissen, V.; Kuyper, T.W.; Mäder, P.; et al. Soil quality—A critical review. Soil Biol. Biochem. 2018, 120, 105-125. [CrossRef]

9. Gabrielsen, P.; Bosch, P. Environmental Indicators: Typology and Use in Reporting; EEA Internal Working Paper; European Environment Agency: Copenhagen, Denmark, 2003.

10. Pittelkow, C.M.; Liang, X.; Linquist, B.A.; van Groenigen, K.J.; Lee, J.; Lundy, M.E.; van Gestel, N.; Six, J.; Venterea, R.T.; van Kessel, C. Productivity limits and potentials of the principles of conservation agriculture. Nature 2015, 517, 365. [CrossRef] [PubMed]

11. Paleari, S. Is the European union protecting soil? A critical analysis of community environmental policy and law. Land Use Policy 2017, 64, 163-173. [CrossRef]

12. Garnett, T.; Appleby, M.C.; Balmford, A.; Bateman, I.J.; Benton, T.G.; Bloomer, P.; Burlingame, B.; Dawkins, M.; Dolan, L.; Fraser, D.; et al. Sustainable Intensification in Agriculture: Premises and Policies. Science 2013, 341, 33-34. [CrossRef] [PubMed]

13. Rockström, J.; Williams, J.; Daily, G.; Noble, A.; Matthews, N.; Gordon, L.; Wetterstrand, H.; DeClerck, F.; Shah, M.; Steduto, P.; et al. Sustainable intensification of agriculture for human prosperity and global sustainability. Ambio 2017, 46, 4-17. [CrossRef] [PubMed]

14. Tittonell, P. Ecological intensification of agriculture-Sustainable by nature. Curr. Opin. Environ. Sustain. 2014, 8, 53-61. [CrossRef]

15. Walter, A.; Finger, R.; Huber, R.; Buchmann, N. Opinion: Smart farming is key to developing sustainable agriculture. Proc. Natl. Acad. Sci. USA 2017, 114, 6148-6150. [CrossRef] [PubMed]

16. Orozco-Mosqueda, M.C.; Rocha-Granados, M.C.; Glick, B.R.; Santoyo, G. Microbiome engineering to improve biocontrol and plant growth-promoting mechanisms. Microbiol. Res. 2018, 208, 25-31. [CrossRef] [PubMed]

17. Techen, A.K.; Helming, K. Pressures on soil functions from soil management in Germany. A foresight review. Agron. Sustain. Dev. 2017, 37, 64. [CrossRef]

18. Podhora, A.; Helming, K.; Adenäuer, L.; Heckelei, T.; Kautto, P.; Reidsma, P.; Rennings, K.; Turnpenny, J.; Jansen, J. The policy-relevancy of impact assessment tools: Evaluating nine years of European research funding. Environ. Sci. Policy 2013, 31, 85-95. [CrossRef]

19. Bond, A.; Pope, J. The state of the art of impact assessment in 2012. Impact Assess. Proj. Apprais. 2012, 30, 1-4. [CrossRef]

20. Reidsma, P.; Janssen, S.; Jansen, J.; van Ittersum, M.K. On the development and use of farm models for policy impact assessment in the European Union-A review. Agric. Syst. 2018, 159, 111-125. [CrossRef]

21. Jónsson, J.Ö.G.; Davíðsdóttir, B.; Jónsdóttir, E.M.; Kristinsdóttir, S.M.; Ragnarsdóttir, K.V. Soil indicators for sustainable development: A transdisciplinary approach for indicator development using expert stakeholders. Agric. Ecosyst. Environ. 2016, 232, 179-189. [CrossRef]

22. Glæsner, N.; Helming, K.; de Vries, W. Do current European policies prevent soil threats and support soil functions? Sustainability 2014, 6, 9538. [CrossRef]

23. Vrebos, D.; Bampa, F.; Creamer, R.; Gardi, C.; Ghaley, B.; Jones, A.; Rutgers, M.; Sandén, T.; Staes, J.; Meire, P. The impact of policy instruments on soil multifunctionality in the European Union. Sustainability 2017, 9, 407. [CrossRef]

24. Juerges, N.; Hansjürgens, B. Soil governance in the transition towards a sustainable bioeconomy-A review. J. Clean. Prod. 2018, 170, 1628-1639. [CrossRef]

25. Wollschläger, U.; Amelung, W.; Brüggemann, B.; Brunotte, B.; Gebbers, R.; Grosch, R.; Heinrich, U.; Helming, K.; Kiese, R.; Leinweber, P.; et al. Soil as a sustainable resource for the bioeconomy-BonaRes. Geophys. Res. Abstr. 2017, 19, 16569.

26. Gomiero, T.; Pimentel, D.; Paoletti, M.G. Is there a need for a more sustainable agriculture? Crit. Rev. Plant Sci. 2011, 30, 6-23. [CrossRef] 
27. Robinson, D.A.; Panagos, P.; Borrelli, P.; Jones, A.; Montanarella, L.; Tye, A.; Obst, C.G. Soil natural capital in Europe; a framework for state and change assessment. Sci. Rep. 2017, 7, 6706. [CrossRef] [PubMed]

28. Borrelli, P.; Panagos, P.; Ballabio, C.; Lugato, E.; Weynants, M.; Montanarella, L. Towards a Pan-European assessment of land susceptibility to wind erosion. Land Degrad. Dev. 2016, 27, 1093-1105. [CrossRef]

29. Hobbs, P.R. Conservation agriculture: What is it and why is it important for future sustainable food production? J. Agric. Sci. 2007, 145, 127-137. [CrossRef]

30. Ghaley, B.B.; Rusu, T.; Sandén, T.; Spiegel, H.; Menta, C.; Visioli, G.; O'Sullivan, L.; Gattin, I.T.; Delgado, A.; Liebig, M.A.; et al. Assessment of Benefits of Conservation Agriculture on Soil Functions in Arable Production Systems in Europe. Sustainability 2018, 10, 794. [CrossRef]

31. Lalani, B.; Aleter, B.; Kassam, S.N.; Bapoo, A.; Kassam, A. Potential for Conservation Agriculture in the Dry Marginal Zone of Central Syria: A Preliminary Assessment. Sustainability 2018, 10, 518. [CrossRef]

32. Nuppenau, E.A. Soil fertility management by transition matrices and crop rotation: On spatial and dynamic aspects in programming of ecosystem services. Sustainability 2018, 10, 2213. [CrossRef]

33. Frelih-Larsen, A.; Hinzmann, M.; Ittner, S. The 'Invisible' subsoil: An exploratory view of societal acceptance of subsoil management in Germany. Sustainability 2018, 10, 3006. [CrossRef]

34. Seydehmet, J.; Lv, G.H.; Nurmemet, I.; Aishan, T.; Abliz, A.; Sawut, M.; Abliz, A.; Eziz, M. Model Prediction of Secondary Soil Salinization in the Keriya Oasis, Northwest China. Sustainability 2018, 10, 656. [CrossRef]

35. Ledermüller, S.; Lorenz, M.; Brunotte, J.; Fröba, N. A multi-data approach for spatial risk assessment of topsoil compaction on arable sites. Sustainability 2018, 10, 2915. [CrossRef]

36. Kautz, T. Nutrient acquisition from arable subsoils in temperate climates: A review. Soil Biol. Biochem. 2013, 57, 1003-1022. [CrossRef]

37. Perry, C. Efficient irrigation; inefficient communication; flawed recommendations. Irrig. Drain. 2007, 56, 367-378. [CrossRef]

38. Helming, K.; Diehl, K.; Bach, H.; Dilly, O.; König, B.; Kuhlman, J.W.; Perez-Soba, M.; Sieber, S.; Tabbush, P.; Tscherning, K.; et al. Ex ante impact assessment of policies affecting land use, part A: Analytical framework. Ecol. Soc. 2011, 16, 27. [CrossRef]

39. Kok, K.; Pedde, S.; Gramberger, M.; Harrison, P.A.; Holman, I.P. New European socio-economic scenarios for climate change research: Operationalising concepts to extend the shared socio-economic pathways. Reg. Environ. Chang. 2018, 1-12. [CrossRef]

40. Food and Agriculture Organization of the United Nations. SAFA Guidelines for Sustainability Assessment of Food and Agriculture Systems, Version 3; FAO: Rome, Italy, 2013.

41. Millenium Ecosystem Assessment (MEA). Ecosystems and Human Wellbeing: Synthesis; Island Press: Washington, DC, USA, 2005.

42. Bartkowski, B.; Hansjürgens, B.; Möckel, S.; Bartke, S. Institutional economics of agricultural soil ecosystem services. Sustainability 2018, 10, 2447. [CrossRef]

43. Schwilch, G.; Lemann, T.; Berglund, Ö.; Camarotto, C.; Cerdà, A.; Daliakopoulos, I.N.; Kohnová, S.; Krzeminska, D.; Marañón, T.; Rietra, R.; et al. Assessing impacts of soil management measures on Ecosystem Services. Sustainability 2018, 10, in print.

44. Correia, P.J.; Pestana, M. Exploratory Analysis of the Productivity of Carob Tree (Ceratonia siliqua) Orchards Conducted under Dry-Farming Conditions. Sustainability 2018, 10, 2250. [CrossRef]

45. Quynh, H.T.; Kazuto, S. “Organic Fertilizers” in Vietnam's Markets: Nutrient Composition and Efficacy of Their Application. Sustainability 2018, 10, 2437. [CrossRef]

46. Hou, Y.; Burkhard, B.; Muller, F. Uncertainties in landscape analysis and ecosystem service assessment. J. Environ. Manag. 2013, 127, S117-S131. [CrossRef] [PubMed]

47. Schwilch, G.; Bernet, L.; Fleskens, L.; Giannakis, E.; Leventon, J.; Marañón, T.; Mills, J.; Short, C.; Stolte, J.; van Delden, H.; et al. Operationalizing ecosystem services for the mitigation of soil threats: A proposed framework. Ecol. Indic. 2016, 67, 586-597. [CrossRef]

48. Stankovics, P.; Tóth, G.; Tóth, Z. Identifying Gaps between the Legislative Tools of Soil Protection in the EU Member States for a Common European Soil Protection Legislation. Sustainability 2018, 10, 2886. [CrossRef]

49. Stubenrauch, J.; Garske, B.; Ekardt, F. Sustainable land use, soil protection and phosphorus management from a cross-national perspective. Sustainability 2018, 10, 1988. [CrossRef]

50. Hansjürgens, B.; Lienkamp, A.; Möckel, S. Justifying Soil Protection and Sustainable Soil Management: Creation-Ethical, Legal and Economic Considerations. Sustainability 2018, 10, 3807. [CrossRef] 
51. Daedlow, K.; Lemke, N.; Helming, K. Arable land tenancy and soil quality in Germany: Contesting theory with empirics. Sustainability 2018, 10, 2880. [CrossRef]

52. Bartkowski, B.; Bartke, S. Leverage points for governing agricultural soils: A review of empirical studies of European Farmers' decision-making. Sustainability 2018, 10, 3179. [CrossRef]

53. Pope Francis. 'Laudato si': On Care for Our Common Home. Available online: http://w2.vatican. $\mathrm{va} /$ content/francesco/en/encyclicals / documents / papafrancesco_20150524_enciclica-laudato-si.html (accessed on 29 October 2018). 